\title{
Analisis Dampak Intrusi Air Laut terhadap Airtanah di Pulau Koral Pramuka, DKI Jakarta
}

\author{
Ahmad Cahyadi, Tjahyo Nugroho Adji, Muh Aris Marfai, Sembodo Noviandaru, dan Romza Fauzan Agniy
}

Fakultas Geografi, Universitas Gadjah Mada, Yogyakarta, Indonesia

Email koresponden ahmadcahyadi@geo.ugm.ac.id

Diterima : April 2017 ; Direvisi : Juli 2017; Dipubikasikan: September 2017

(C) 2017 Fakultas Geografi UGM dan Ikatan Geograf Indonesia.

Abstrak Pulau Koral Pramuka merupakan salah satu pulau yang memiliki fungsi strategis sebagai Ibukota Kabupaten Kepulauan Seribu, DKI Jakarta. Pembangunan yang terus berlangsung untuk mendukung fungsi sebagai ibukota sekaligus sebagai tujuan wisata menjadikan pertumbuhan penduduk tinggi dan kebutuhan akan sumberdaya air terus meningkat. Kondisi demikian dapat menyebabkan ancaman intrusi air laut menjadi semakin tinggi karena jumlah pengambilan airtanah akan semakin bertambah. Penelitian ini bertujuan untuk mengetahui dampak intrusi air laut terhadap airtanah di Pulau Koral Pramuka. Metode yang digunakan adalah analisis daya hantar listik (DHL) airtanah serta perbandingan ion klorida dan ion karbonat dalam airtanah. Data yang digunakan dalam penelitian ini adalah nilai DHL, kandungan ion klorida dan bikarbonat yang diambil dari sampel airtanah. Sampel diambil secara sistematis berdasarkan grid berukuran 100 meter x 150 meter. Total sampel airtanah adalah sejumlah 23 sampel. Hasil kajian menunjukkan bahwa 15 sampel airtanah menunjukkan bahwa intrusi telah berpengaruh cukup besar terhadap airtanah, sedangkan 8 sampel menunjukkan bahwa intrusi telah berpengaruh besar terhadap airtanah di Pulau Koral Pramuka.

Kata kunci : Airtanah, Intrusi, Bikarbonat, Klorida, Pulau Koral Pramuka

Abstract Pramuka Cay, one of the islands in Kepulauan Seribu Regency, Jakarta, has a strategic role as the capital district. The constant development, which aims to support the functions as a capital district and a tourist destination, persistently increases population growth and, at the same time, demand for water resource. This condition may intensify the threats of seawater intrusion as it induces a higher groundwater withdrawal. This research aimed to identify the impact of seawater intrusion on groundwater in Pramuka Cay using electrical conductivity (EC) analysis and comparison analysis of the chloride and bicarbonate ions in the groundwater. The research data, including EC and the concentration of chloride and bicarbonate ions, were obtained from groundwater samples. The 23 samples were selected systematically from $100 \times 150 \mathrm{~m} 2$ grids. The analysis of 15 samples found a rather significant impact of seawater intrusion on groundwater, whereas the test results on the remaining 8 samples showed that seawater intrusion had affected the groundwater in Pramuka Cay considerably.

Keywords: Groundwater, Intrusion, Bicarbonate, Chloride, Pramuka Cay

\section{PENDAHULUAN}

Potensi sumberdaya pesisir dan kelautan yang dimiliki Indonesia sangat besar (Cahyadi dkk., 2013). Potensi yang besar tersebut disebabkan karena luasnya wilayah Indonesia, garis pantai yang sangat panjang, jumlah pulau yang banyak dan keanekaragaman hayati yang tinggi (Uar dkk., 2016). Pulau Koral Pramuka merupakan salah satu pulau yang tergolong sebagai pulau kecil karena memiliki luas kurang dari 2.000 $\mathrm{km}^{2}$, meskipun sebenarnya dalam tinjauan hidrologi pulau koral ini masuk dalam kategori pulau sangat kecil (Cahyadi, 2012; Cahyadi dan Tivianton, 2013). Pulau Koral Pramuka memiliki fungsi administrasi yang vital karena merupakan ibukota kabupaten Kepulauan Seribu, Provinsi DKI Jakarta.

Pulau Koral Pramuka dihuni oleh 1.715jiwa. Selain jumlah penduduk yang terus meningkat Pulau Koral Pramuka merupakan daerah pariwisata yang cukup popular. Hal ini dibuktikan dengan jumlah wisatawan yang berkunjung pada tahun 2010 sebesar 50.189 wisatawan, dan jumlahnya cenderung meningkat setiap tahunnya (Suku Dinas Pariwisata dan Kebudayaan Kepulauan Seribu, 2012, Cahyadi dkk, 2013; Cahyadi dkk., 2015a).

Besarnya jumlah penduduk dan jumlah wisatawan akan berdampak pada kebutuhan air bersih yang semakin meningkat (Dökmen, 2012; Asrifah, 2013; Naderi et al., 2013; Christina et al., 2014). Salah satu sumber air bersih yang dapat dimanfaatkan yaitu adalah sumber air yang berasal dari airtanah (Cahyadi, 2012). Sumberdaya airtanah di daerah pulau kecil memiliki kondisi yang khas (Sinulingga dkk., 2015). Sumberdaya air di pulau kecil terdiri dari airtanah, air permukaan berupa air sungai, mata air, danau, dan juga air hujan. Namun demikian, Gilli et al. (2012) menyebutkan bahwa pada pulau koral kecil biasanya potensi sumberdaya air hanya berupa airtanah dan air hujan. Selain itu, airtanahnya juga rawan terhadap intrusi air laut dan mudah untuk tercemar (White et al., 1999; Gilli et al., 2012; Naderi et al., 2013; Cahyadi dkk., 
2015b).

Definisi bencana menurut Kodoatie dan Syarief (2006) merupakan suatu kejadian yang terjadi secara tiba-tiba dan menimbulkan dampak yang besar, sehingga masyarakat perlu merespon dengan tindakan yang besar pula. Naskah akademik RUU tentang Penanggulangan Bencana menyebutkan "bencana merupakan suatu gangguan serius terhadap keberfungsian suatu masyarakat sehingga menyebabkan kerugian yang meluas pada kehidupan manusia dari segi materi, ekonomi atau lingkungan dan yang melampauikemampuan masyarakat tersebut untuk mengatasi dengan menggunakan sumber-sumber data mereka sendiri" (Panja Komisi VIII DPR RI, 2005). Berdasarkan definisi yang tercantum dalam naskah RUU tersebut, maka intrusi air laut dapat dikategorikan sebagai bencana. Hal tersebut dikarenakan intrusi menimbulkan kerugian yang meluas terutama untuk aspek lingkungan. Intrusi adalah proses yang berpotensi merubah sifat dan kandungan kimiawi, biologi, dan fisika airtanah. Menyadari bahwa intrusi merupakan salah satu aspek sumber bencana, maka kajian mengenai intrusi ini menjadi penting (Dökmen, 2012; Felisa et al., 2013)

Suhartono et al. (2015) menyebutkan bahwa kondisi kontaminasi dari intrusi dari air laut dapat diidentifikasi melalui besaran kandungan ion klorida $(\mathrm{Cl})$. Hal ini dikarenakan kandungan garam $(\mathrm{NaCl})$ pada air laut terbentuk atas $39,3 \%$ sodium $(\mathrm{Na})$ dan $60,7 \%$ klorida $(\mathrm{Cl})$, sehingga besaran nilai $\mathrm{Cl}$ ini cukup mampu menggambarkan besarnya pengaruh intrusi air laut dalam airtanah. Airtanah dalam kondisi fresh memiliki kecenderungan ion bikarbonat yang besar, hal ini seperti di ungkapkan oleh El Moujabber et al. (2006); Purnama (2010) dan Tomaszkiewicz, et al. (2014). Ion bikarbonat $\left(\mathrm{HCO}_{3}^{-}\right)$dan karbonat $\left(\mathrm{CO}_{3}{ }^{2-}\right)$ serta kalsium $\left(\mathrm{Ca}^{2+}\right)$ merupakan ion yang dominan pada airtanah yang tawar. Metode lain yang cukup mudah dalam menggambarkan pengaruh air asin yang ditunjukan dalam salinitas yaitu dengan menggunakan parameter total dissolve solid (TDS) dan electrical conductivity (EC) (Rhoades et al., 1992; Singhal and Gupita, 2010; Darmanto dan Cahyadi, 2013; Cahyadi dkk., 2013).

Tujuan dari penelitian ini yaitu untuk mengetahui dampak intrusi laut terhadap kondisi airtanah di Pulau Koral Pramuka. Dampak yang dimaksud didasarkan pada klasifikasi nilai Daya Hantar Listrik (DHL) serta perbandingan ion klorida dan bikarbonat. Penelitian ini diharapkan dapat memberikan gambaran terkait kondisi sumberdaya airtanah di Pulau Koral Pramuka secara khusus, dan pulau koral dengan ukuran sangat kecil pada umumnya.

\section{METODE PENELITIAN}

Alat yang digunakan dalam penelitian terkait kualitas airtanah di Pulau Koral Pramuka yaitu Global Posittioning System (GPS) yang digunakan untuk menentukan letak geografis dari titik pengambilan sampel airtanah, botol sampel digunakan sebagai media penyimpanan sampel airtanah, seperangkat alat water quality test kit untuk pengukuran nilai DHL, software Microsoft Office yang digunakan untuk mengolah data, software Arc GIS 9.3 yang digunakan untuk mengolah data spasial, sedangkan bahan yang digunakan mencakup data hasil analisis laboratorium untuk kualitas air yang mencakup nilai ion klorida $\left(\mathrm{Cl}^{-}\right)$ dan bikarbonat $\left(\mathrm{HCO}_{3}^{-}\right)$.

Metode pengambilan sampel dilakukan dengan menggunakan metode systematic sampling dengan memanfaatkan grid-grid berukuran 150 x $100 \mathrm{~m}$ (Gambar 1). Masing-masing grid kemudian diambil satu titik pengambilan sampel airtanah dengan mempertimbangkan letak yang bisa menggambarkan tiap gridnya. Berdasarkan grid tersebut didapati sejumlah 23 titik pengambilan data. Parameter yang diuji langsung di lapangan mencakup data DHL. Pengukuran dilakukan dengan menggunakan alat water quality test kit dengan EC meter di dalamnya. Pengambilan sampel pada tiap titik dilakukan dengan menggunakan botol sampel pada sumur hasil pengeboran dengan bor tangan yang kemudian dilakukan uji laboratorium yang mencakup unsur mayor klorida $\left(\mathrm{Cl}^{-}\right)$dan bikarbonat $\left(\mathrm{HCO}_{3}^{-}\right)$.

Analisis data yang dilakukan mencakup analisis data terhadap nilai DHL dan juga analisis data untuk perbandingan nilai ion klorida $\left(\mathrm{Cl}^{-}\right)$dan bikarbonat $\left(\mathrm{HCO}_{3}^{-}\right)$. Analisis DHL dilakukan dengan memanfaatkan klasifikasi yang diadaptasi dari Rhoades et al.(1992) (Tabel 1). 

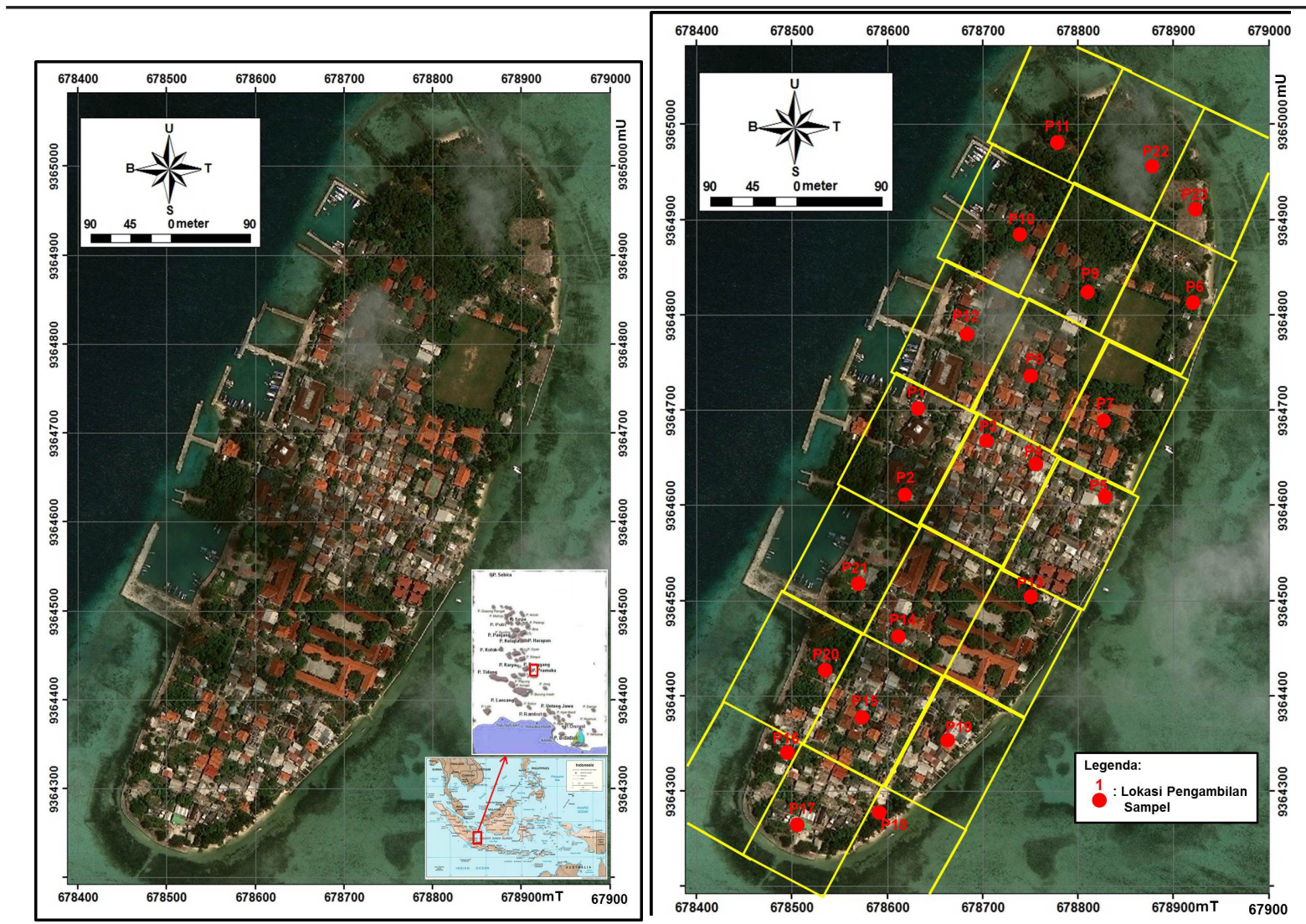

Gambar 1. Letak Pulau Pramuka di Kepulauan Seribu (kiri) dan Lokasi Pengambilan Sampel Airtanah di Pulau Koral Pramuka (kanan)

Tabel 1. Klasifikasi Air Berdasarkan Daya Hantar Listrik (Electrical Conductivity/ EC)

\begin{tabular}{lr}
\hline \multicolumn{1}{c}{ Kelas } & \multicolumn{1}{c}{$\mathrm{EC}(\mu \mathrm{S} / \mathrm{cm})$} \\
\hline Air Tawar & $<700$ \\
Airtanah sedikit asin & $700-2000$ \\
Airtanah asin tingkat sedang & $2.000-10.000$ \\
Airtanah asin tingkat tinggi & $10.000-20.000$ \\
Airtanah asin tingkat sangat tinggi & $20.000-45.000$ \\
Air laut & $>45.000$ \\
\hline
\end{tabular}

Sumber : Rhoades et al. (1992) dengan Modifikasi

Analisis pengaruh intrusi air laut dilakukan dengan menggunakan analisis perbandingan ion klorida $\left(\mathrm{Cl}^{-}\right)$dengan ion bikarbonat $\left(\mathrm{HCO}_{3}^{-}\right)$(aris et al., 2013). Kriteria ini kemudian dapat diklasifikasikan berdasarkan besaran pengaruh dari intrusi air laut yang terjadi pada setiap titik sampel yang diambil. Pengaruh intrusi air laut terhadap airtanah kemudian diklasifikasikan berdasarkan klasifikasi Purnama (2010) (Tabel 2). Berdasarkan hasil analisis nantinya akan dapat diketahui besaran dampak dari intrusi air laut yang terjadi di Pulau Koral Pramuka, Kepulauan Seribu, DKI Jakarta.
Tabel 2. Klasifikasi Besaran Pengaruh Intrusi Air Laut Terhadap Kondisi Airtanah

\begin{tabular}{|c|c|c|}
\hline $\begin{array}{c}\text { Kelas } \\
\text { Tingkat } \\
\text { pengaruh }\end{array}$ & $\begin{array}{c}\text { Keterangan } \\
\text { Tingkat Pengaruh }\end{array}$ & $\begin{array}{c}\text { Nilai } \\
\text { Perbandingan }\end{array}$ \\
\hline 1 & $\begin{array}{l}\text { Tidak terdapat } \\
\text { pengaruh air asin }\end{array}$ & $\leq 0,50$ \\
\hline 2 & $\begin{array}{l}\text { Pengaruh air asin } \\
\text { kecil }\end{array}$ & $0,51-1,50$ \\
\hline 3 & $\begin{array}{l}\text { Pengaruh air asin } \\
\text { sedang }\end{array}$ & $1,50-3,00$ \\
\hline 4 & $\begin{array}{l}\text { Pengaruh air asin } \\
\text { cukup besar }\end{array}$ & $3,01-6,50$ \\
\hline 5 & $\begin{array}{l}\text { Pengaruh air asin } \\
\text { besar }\end{array}$ & $6,51-15,50$ \\
\hline 6 & $\begin{array}{l}\text { Pengaruh air asin } \\
\text { sangat besar }\end{array}$ & $\geq 15,50$ \\
\hline
\end{tabular}

Sumber : Purnama (2010)

\section{HASIL DAN PEMBAHASAN}

Analisis pengaruh intrusi air laut terhadap airtanah yang terjadi di Pulau Koral Pramuka dilakukan dengan menggunakan dua metode yaitu dengan menggunakan data daya hantar listrik dan metode perbandingan ion. Perbandingan ion dilakukan dengan membandingkan ion klorida $\left(\mathrm{Cl}^{-}\right)$dengan ion bikarbonat $\left(\mathrm{HCO}_{3}^{-}\right)$. 
Daya hantar listrik memiliki kecenderungan akan meningkat apabila terdapat ion-ion garam yang semakin besar pada suatu larutan. Berdasarkan pengukuran terhadap 23 sampel yang diambil, nilai DHL menunjukan 5 jenis tingkat pengaruh air asin berdasarkan nilai klasifikasi dari Rhoades et al (1992) (Tabel 3). Beberapa nilai tersebut mencakup klasifikasi airtanah sedikit asin (sampel P9), airtanah asin tingkat sedang (P6, P7, P8, P13,P14, P16, dan P17), airtanah asin tingkat tinggi (P3, P4, P10, dan P15), serta Airtanah asin tingkat sangat tinggi dengan nilai daya hantar listrik (DHL) di atas $20.000 \mu \mathrm{S} / \mathrm{cm}$ (Gambar 3). Berdasarkan nilai DHL tersebut dapat teridentifikasi bahwasannya airtanah di Pulau Koral Pramuka secara keseluruhan telah terpengaruh intrusi air laut. Hal ini nampak dari nilai variasi DHL tidak ada yang memiliki nilai di bawah $700 \mu \mathrm{S} / \mathrm{cm}$. Sebaran DHL dengan tingkat pengaruh intrusi yang tinggi terdistribusi hampir di seluruh sampel yang diambil pada daerah yang berdekatan dengan laut, sedangkan airtanah pada daerah yang berada di tengah pulau memiliki variasi nilai yang lebih rendah dari airtanah sedikit asin hingga airtanah asin tingkat sedang.

Lebih kecilnya nilai DHL pada bagian tengah pulau bisa terjadi karena airtanah pada tepi pulau dipengaruhi pula oleh aktivitas arus, gelombang dan pasang surut (Cahyadi dkk, 2013). Hal ini memungkinkan daerah ini secara berkala mendapatkan tekanan yang besar dari air laut, sehingga proses masuknya air laut ke dalam airtanah menjadi lebih mudah. Kondisi berbeda terjadi pada tengah pulau di mana kondisi air masuk dalam klasifikasi sedikit asin hingga asin sedang karena pengaruh tekanan air asin relatif paling kecil dibandingkan dengan wilayah di pinggiran pulau.

Tabel 3. Sebaran nilai DHL Airtanah di Pulau Koral Pramuka

\begin{tabular}{|c|c|c|c|c|c|}
\hline No & $\begin{array}{c}\text { DHL } \\
(\mu \mathrm{S} / \mathrm{cm})\end{array}$ & Kelas & No & $\begin{array}{c}\text { DHL } \\
(\mu \mathrm{S} / \mathrm{cm})\end{array}$ & Kelas \\
\hline $\mathrm{P} 1$ & $>20.000$ & Airtanah asin tingkat sangat tinggi & P13 & 3.200 & Airtanah asin tingkat sedang \\
\hline $\mathrm{P} 2$ & $>20.000$ & Airtanah asin tingkat sangat tinggi & P14 & 4.800 & Airtanah asin tingkat sedang \\
\hline P3 & 11.200 & Airtanah asin tingkat tinggi & P15 & 12.200 & Airtanah asin tingkat tinggi \\
\hline $\mathrm{P} 4$ & 12,300 & Airtanah asin tingkat tinggi & P16 & 2.800 & Airtanah asin tingkat sedang \\
\hline P5 & $>20.000$ & Airtanah asin tingkat sangat tinggi & P17 & 7.300 & Airtanah asin tingkat sedang \\
\hline P6 & 6.200 & Airtanah asin tingkat sedang & P18 & $>20.000$ & Airtanah asin tingkat sangat tinggi \\
\hline P7 & 7200 & Airtanah asin tingkat sedang & P19 & $>20.000$ & Airtanah asin tingkat sangat tinggi \\
\hline P8 & 6.800 & Airtanah asin tingkat sedang & P20 & $>20.000$ & Airtanah asin tingkat sangat tinggi \\
\hline P9 & 1.600 & Airtanah Sedikit Asin & $\mathrm{P} 21$ & $>20.000$ & Airtanah asin tingkat sangat tinggi \\
\hline P10 & 12.200 & Airtanah asin tingkat tinggi & P22 & $>20.000$ & Airtanah asin tingkat sangat tinggi \\
\hline P11 & $>20.000$ & Airtanah asin tingkat sangat tinggi & $\mathrm{P} 23$ & $>20.000$ & Airtanah asin tingkat sangat tinggi \\
\hline P12 & $>20.000$ & Airtanah asin tingkat sangat tinggi & & & \\
\hline
\end{tabular}

Sumber: Hasil Pengukuran Lapangan

Analisis tingkat pengaruh air laut terhadap airtanah dalam penelitian ini juga ditunjukan dengan nilai perbandingan ion klorida $\left(\mathrm{Cl}^{-}\right)$dengan ion bikarbonat $\left(\mathrm{HCO}_{3}^{-}\right.$) (Tabel 4). Berdasarkan nilai perbandingan tersebut diketahui terdapat 2 klasifikasi tingkat pengaruh intrusi air laut terhadap airtanah berdasarkan klasifikasi Purnama (2010) (Gambar 2). Klasifikasi pertama menunjukan airtanah terpengaruh air asin cukup besar sebanyak 15 sampel yaitu pada sampel nomor 3, 7, 8, 9, 10, 13, 14, 15, 16,17, 18, 19, 20,22 , dan 23 , sedangkan klasifikasii kedua masuk dalam airtanah terpengaruh intrusi air laut besar sejumlah 8 sampel yaitu mencakup sampel nomor 1,2,
4, 5, 6, 11,12, dan 21. Berdasarkan hasil tersebut maka Pulau Koral Pramuka memiliki kondisi airtanah yang telah terpengaruh air laut cukup signifikan. Hal ini dikarenakan data menunjukan nilai ion klorida $(\mathrm{Cl})$ yang lebih tinggi, sehingga dominasi ion-ion seperti $\mathrm{HCO}_{3}^{-}$yang merupakan ion penciri dari airtanah tawar (fresh groundwater) selain $\mathrm{CO}_{3}^{2-}$ dan $\mathrm{Ca}^{2+}$ menjadi tidak dominan.

Pengaruh intrusi air laut dapat berkurang apabila input dari curah hujan yang menjadi suplai utama di Pulau Koral Pramuka ini dapat terserap secara optimal, sehingga memungkinkan untuk menekan jumlah dominasi ion-ion seperti $\mathrm{Cl}$, walaupun pada 
dasarnya pengaruh intrusi ini sulit untuk dihilangkan. Namun demikian, apabila pemanfaatan lahan dan pembangunan ke arah peruntukan lahan yang memungkinkan bidang resapan berkurang, maka air hujan akan terlimpas langsung menuju laut, sehingga potensi meresap ke airtanah akan semakin kecil (Cahyadi, 2012). Luasan wilayah yang terbatas dan jumlah resapan air yang kecil menyebabkan kuantitas airtanah daerah Pulau Koral Pramuka menjadi kecil. Selain itu, pembangunan pemukiman dan fasilitas penunjang lainnya yang membutuhkan suplai air yang besar juga dapat memperburuk pengaruh intrusi air laut terhadap kondisi airtanah setempat. Hal tersebut dikarenakan akan memicu munculnya titik-titik upconing yang mampu menarik air asin masuk kedalam sistem airtanah.

Tabel 4. Hasil Uji Kualitas Air untuk $\mathrm{Cl}^{-}$dan $\mathrm{HCO}_{3}$ - dan Perbandingan Keduanya

\begin{tabular}{cccccccc}
\hline No & $\begin{array}{c}\mathrm{Cl} \\
(\mathrm{meq} / \mathrm{l})\end{array}$ & $\begin{array}{c}\mathrm{HCO} 3 \\
(\mathrm{meq} / \mathrm{l})\end{array}$ & $\begin{array}{c}\mathrm{Cl} / \mathrm{HCO} 3 \\
(\mathrm{meq} / \mathrm{l})\end{array}$ & No & $\begin{array}{c}\mathrm{Cl} \\
(\mathrm{meq} / \mathrm{l})\end{array}$ & $\begin{array}{c}\mathrm{HCO} 3 \\
(\mathrm{meq} / \mathrm{l})\end{array}$ & $\begin{array}{c}\mathrm{Cl} / \mathrm{HCO} 3 \\
(\mathrm{meq} / \mathrm{l})\end{array}$ \\
\hline P1 & 39.48 & 4.85 & 8.14 & $\mathrm{P} 13$ & 17.48 & 3.93 & 4.44 \\
P2 & 36.94 & 5.18 & 7.13 & $\mathrm{P} 14$ & 18.05 & 3.61 & 5.01 \\
P3 & 22.28 & 5.70 & 3.91 & $\mathrm{P} 15$ & 24.25 & 4.00 & 6.06 \\
P4 & 25.38 & 3.15 & 8.07 & $\mathrm{P} 16$ & 14.66 & 4.20 & 3.49 \\
P5 & 42.02 & 5.05 & 8.32 & $\mathrm{P} 17$ & 21.43 & 4.39 & 4.88 \\
P6 & 30.46 & 4.26 & 7.15 & $\mathrm{P} 18$ & 22.00 & 4.20 & 5.24 \\
P7 & 22.56 & 5.77 & 3.91 & $\mathrm{P} 19$ & 18.89 & 4.13 & 4.57 \\
P8 & 18.33 & 4.72 & 3.88 & $\mathrm{P} 20$ & 27.64 & 4.59 & 6.02 \\
P9 & 21.15 & 4.85 & 4.36 & $\mathrm{P} 21$ & 34.40 & 4.59 & 7.50 \\
P10 & 20.87 & 5.64 & 3.70 & $\mathrm{P} 22$ & 22.00 & 3.93 & 5.59 \\
P11 & 31.30 & 3.54 & 8.84 & $\mathrm{P} 23$ & 22.84 & 4.06 & 5.62 \\
P12 & 34.40 & 3.74 & 9.21 & & & & \\
\hline
\end{tabular}

Sumber: Hasil Analisis Data

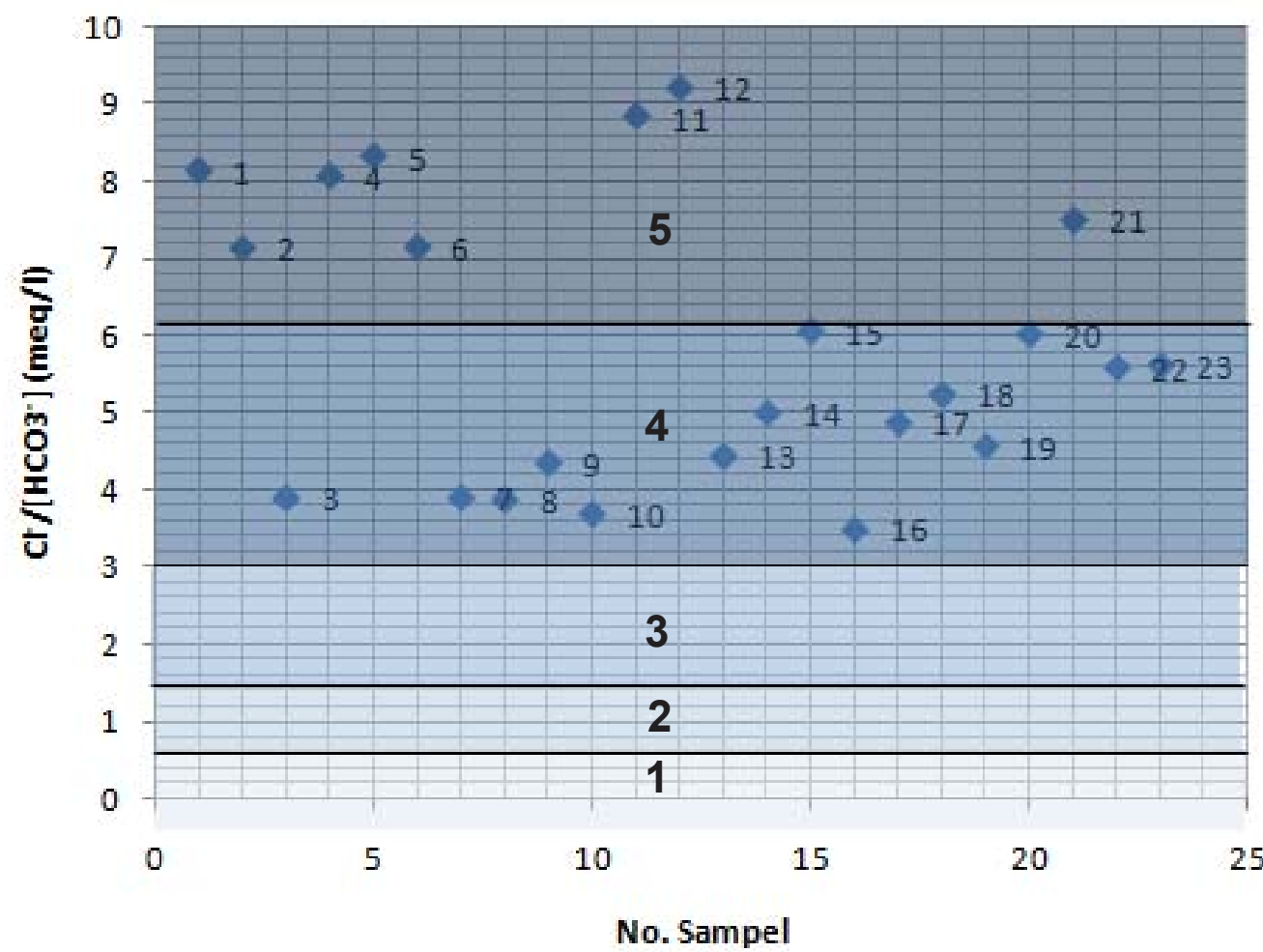

Gambar 2. Sebaran Data Perbandingan Ion Klorida Terhadap Ion Bikarbonat pada Airtanah di Pulau Koral Pramuka 


\section{KESIMPULAN}

Berdasarkan hasil penelitian ini dapat disimpulkan bahwa secara keseluruhan kondisi airtanah di Pulau Koral Pramuka telah mengalami pengaruh intrusi air laut. Hal ini di tunjukan dengan nilai daya hantar listrik (DHL) berkisar antara 2.800->20.000 $\mu \mathrm{S} / \mathrm{cm}$ atau masuk kategori airtanah sedikit asin hingga airtanah asin tingkat tinggi. Selain itu perbandingan ion klorida $\left(\mathrm{Cl}^{-}\right)$dengan ion bikarbonat $\left(\mathrm{HCO}_{3}^{-}\right)$juga menunjukan nilai pengaruh air laut yang tinggi terhadap airtanah. Berdasarkan perbandingan ion $\mathrm{Cl}^{-}$dengan $\mathrm{HCO}_{3}$ teridentifikasi bahwa keseluruhan airtanah wilayah terindikasi terpengaruh air laut cukup besar (nilai perbandingan 3,01-6,50) dan airtanah terpengaruh air asin yang besar (nilai perbandingan 6,51-15,50).

\section{UCAPAN TERIMA KASIH}

Penelitian ini merupakan bagian dari tesis penulis pertama. Terimakasih kami sampaikan kepada Dini Feti Anggraini, Andung Bayu Sekaranom, Annisa Triyanti, Dias Ery Baswendro, Hendy Fatchurohman yang telah membantu kegiatan penelitian di Pulau Koral Pramuka. Terima kasih kami sampaikan kepada Pengelola Magister Perencanaan Pengelolaan Pesisir dan Daerah Aliran Sungai Fakultas Geografi Universitas Gadjah Mada atas segala fasilitas dan bantuan yang mendukung kegiatan penelitian ini. Ucapan terimakasih juga kami sampaikan kepada Prof. Dr. Ig.L. Setyawan Purnama, M.Si. dan Dr. Slamet Suprayogi, M.S. dari Fakultas Geografi UGM yang telah memberikan beberapa masukan dalam penelitian ini.

\section{DAFTAR PUSTAKA}

Aris, A.Z.; Praveena, S.M. dan Isa, N.M. (2013). Groundwater Composition and Geochemical Controls in Small Tropical Island of Malaysia: A Comparative Study. dalam Wetzelhuetter, C. (ed). 2013. Groundwater in The Coastal Zones of AsiaPacific. Dordrecht: Springer.

Asrifah, D. (2013). Evaluasi Potensi Airtanah Bebas untuk Penyediaan Air di Kalasan dan Prambanan. Majalah Geografi Indonesia, 27 (1): 56 - 78.

Cahyadi, A. (2012). Permasalahan Sumberdaya Air di Pulau Karang Sangat Kecil (Studi Kasus di Pulau Pramuka, Kabupaten Kepulauan Seribu, DKI Jakarta). Prosiding Seminar Nasional Pengelolaan Sumberdaya Alam dan Lingkungan. Semarang: Program Studi Ilmu Lingkungan Universitas Diponegoro.

Cahyadi,A.;Hidayat, W.dan Wulandari.(2013).Adaptasi Masyarakat Terhadap Keterbatasan Sumberdaya Air di Pulau Pramuka, Kepulauan Seribu, DKI Jakarta. Jurnal Penelitian Kesejahteraan Sosial, 12 (2): $207-213$.
Cahyadi, A. dan Tivianto, T.A. (2013). Persepsi Masyarakat Terhadap Pemanenan Air Hujan dan Dampaknya Terhadap Ketahanan Sumberdaya Air di Pulau Pramuka, Kepulauan Seribu, DKI Jakarta. dalam Marfai, M.A. dan Widyastuti, M. 2013. Pengelolaan Lingkungan Zamrud Khatulistiwa. Yogyakarta: Buku Pintal.

Cahyadi, A.; Marfai, M.A.; Tivianton, T.A.; Wulandari dan Hidayat, W. (2015a). Menyelamatkan Masa Depan Pulau-Pulau Kecil Indonesia. Prosiding Sarasehan Nasional Geografi Tahun 2013. Yogyakarta: Fakultas Geografi Universitas Gadjah Mada.

Cahyadi, A.; Agniy, R.F. dan Suhana, S.N. (2015b). Karakterisasi Hidrogeokimia Airtanah untuk Analisis Genesis Airtanah di Pulau Koral Sangat Kecil. Prosiding Seminar Nasional Ke-1 dalam Pengelolaan Pesisir dan Daerah Aliran Sungai. Yogyakarta: Magister Perencanaan Pengelolaan Pesisir dan Daerah Aliran Sungai, Fakultas Geografi, Universitas Gadjah Mada.

Christina, G.; Konstantinos, S.; Alexandros, G.; Dimitrios, K. dan Alkaterini, K. (2014). Seawater Intrusion and Nitrate Pollution in Coastal Aquifer of Almyros- Nea Anchialos Basin, Central Greece. WSEAS Transactions on Environment and Development, 10: 211 - 222.

Darmanto, D. dan Cahyadi, A. (2013). Kajian Intrusi Air Laut Melalui Sungai di Pesisir Kabupaten Demak Jawa Tengah. Majalah Geografi Indonesia, 27 (1): 1 - 10 .

Dökmen, F. (2012). Salinity and Seawater Intrusion into the Ground Water. Indian Journal of Science and Technology, 5 (12): $72-77$.

El Moujabber, M.; Bou Samra, B.; Darwish, T. dan Atallah, T. (2006). Comparison of Different Indicators for Groundwater Contamination by Seawater Intrusion on the Lebanese Coast. Water Resources Management, 20: 161 - 180.

Felisa, G.; Ciriello, V. dan Federico, V.D. (2013). Saltwater Intrusion in Coastal Aquifers: A Primary Case Study along the Adriatic Coast Investigated within a Probabilistic Framework. Water, 5: 1830 $-1847$.

Gilli, E.; Mangan, C. dan Mudry, J. (2012). Hydrogeology: Objectives, Methods, Applications, diterjemahkan dari Bahasa Perancis oleh Chloe Fandel. Boca Raton: CRC Press.

Kodoatie, R.J. dan Sjarief, R. (2006). Pengelolaan Bencana Terpadu. Jakarta : Yarsif Watampone.

Naderi, M.N.; Kermani, M.R.H. dan Barani, G.A. 2013. European Journal of Experimental Biology, 3 (3): $80-94$. 
Panja (Panitia Kerja) Komisi VIII DPR RI. (2005). Naskah AkademikRancangan Undang-Undang RI Nomor 24 Tahun 2007 Tentang Penanggulangan Bencana.

Purnama, S. (2010). Hidrologi Airtanah. Yogyakarta: Penerbit Kanisius.

Rhoades, J.D., Kandiah, A. dan Mashali, A., (1992). The Use of Saline Waters for Crop Production. Roma: FAO.

Singhal, B., dan Gupta, R.P., (2010). Applied Hydrogeology of Fractured Rocks. Springer.

Sinulingga, R.; baiquni, M. dan Purnama, S. (2015). PengelolaanSumberdayaAiruntukPengembangan Pariwisata di Pulau Pari, Kepulauan Seribu, DKI Jakarta. Majalah Geografi Indonesia, 29 (2): 177 186.

Suhartono, E; Purwanto P.; dan Suripin S. (2015). Seawater Intrusion Modeling On Groundwater Confined Aquifer In Semarang. Procedia Environmental Sciences 23: 110-115.

Suku Dinas Pariwisata dan Kebudayaan Kepulauan Seribu. (2012). Pengembangan Kepariwisataan dan Kebudayaan Kepulauan Seribu. Jakarta : Suku Dinas Pariwisata dan Kebudayaan Kepulauan Seribu.

Tomaszkiewicsz, M., Najm, M.A., dan El-Fadel, M. (2014). Development of A Groundwater Quality Index for Seawater Intrusion in Ncoastal Aquifers. Environmental Modelling \& Software, 57: 13-26.

Uar, N.T.; Murti, S.H. dan Hadisusanto, S. (2016). Kerusakan Lingkungan Akibat Aktivitas Manusia pada Ekosistem Terumbu Karang. Majalah Geografi Indonesia, 30(1): 88 - 95.

White, I.; Falkland, C.A.; Crennan, L.; Jones, P.; Metutera,T.; Etuati, B. dan Metai, E. (1999). Issues, Traditions and Conflicts in Groundwater Use and Management. Paris: UNESCO. 